\title{
dsRed(RNAi) APC-1(RNAi)
}

ptc(RNAi)

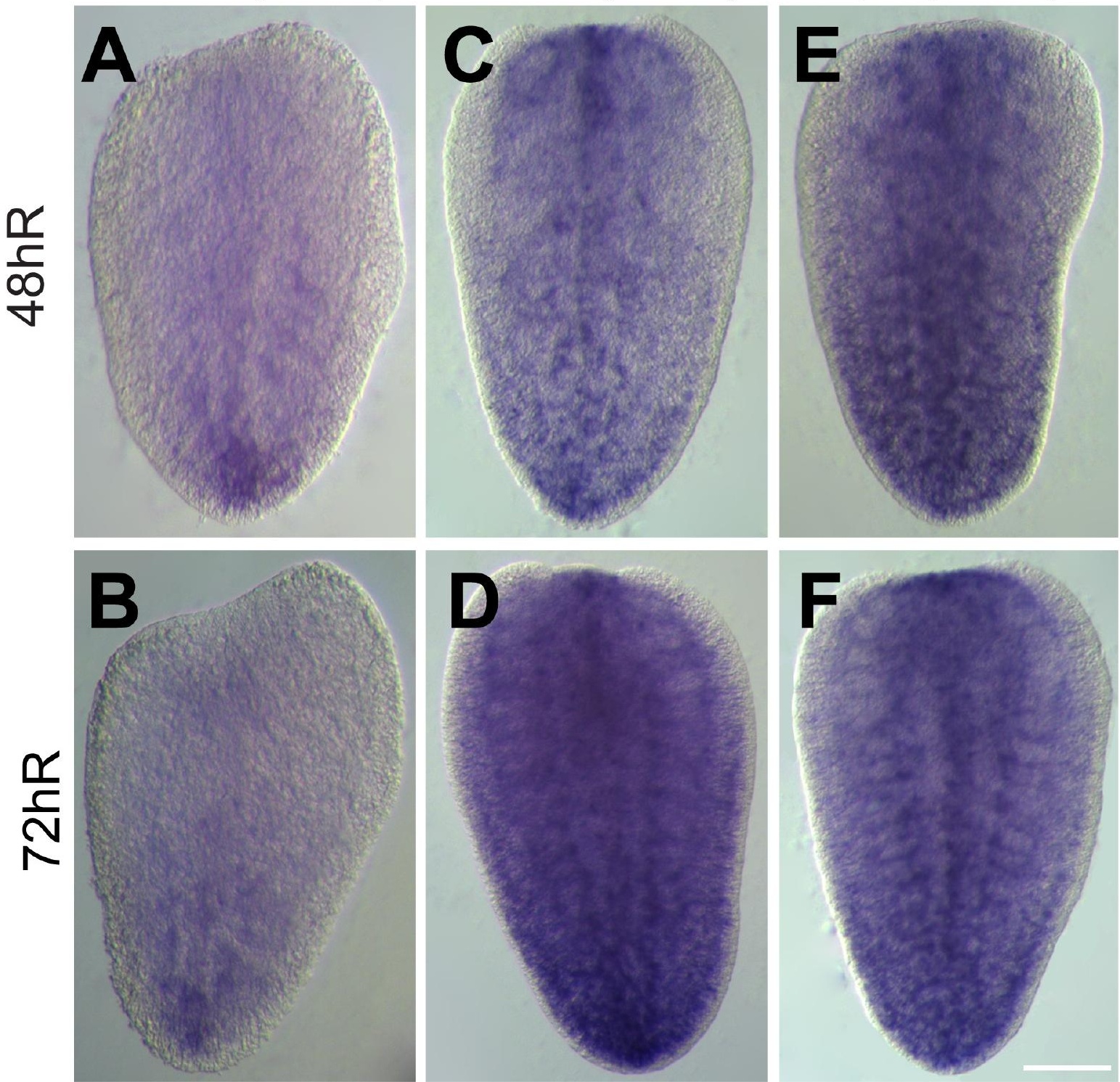

